\title{
SERAT GATHOLOCO: TUBUH MENGGUGAT AGAMA
}

\author{
Syihabul Furqon \\ Program Magister Religious Studies pascasarjana UIN Sunan gunung Djati Bandung Jl.A.H Nasution 105 Cibiru, \\ Bandung 40614.Indonesia Email: syihabulhajj2@gmail.com
}

\section{Busro}

Fakultas Ushuluddin UIN Sunan gunung Djati Bandung Jl.A.H Nasution 105 Cibiru, Bandung 40614.Indonesia Email: busro@uinsgd.ac.id

\begin{abstract}
The new era of Islam is characterized by the interdependence of the modern world that is inaccessible to the presence and primordiality of the full tradition. This opposition is as strong and stubborn as it is always accompanied by criticisms of two trends: excesses to modernity or tradition. The language as an interstitial is made very plastic and allows the thinker, the genius of his day to pour their ideas into their tendencies. Because Pakistan holds its belief, modernity also provides its firmness through language. One of them is in a series of critical religions and elements of vulgar erotic elements: Gatholoco. The contents of the contextual religious debate about time, this fiber, even for the present context, can still be a new direction. Back in touch with orientation and affirmation of the body - not abolished.
\end{abstract}

Keywords:

Critics; Tradition; Modern; Language; Body; Myth; Culture; Sufism.

\begin{abstract}
Abstrak
Era baru Islam ditandai oleh saling bertautnya antara dunia modern yang tak bisa dihalau kedatangannya dan primordialitas tradisi yang penuh kebijaksanaan. Pertentangan ini sama kuat dan keras sebagaimana ia selalu datang bersama kritik atas dua kecenderungan: baik akses ke arah modernitas atau tradisi. Pada gilirannya bahasa sebagai pengantara dibuat sedemikian praktis dan memungkinkan para pemikir, jenius zamannya menuangkan gagasan mereka kecenderungan mereka. Sebagaimana otoritas agama berpegang teguh pada keyakinannya, modernitas juga memberikan keteguhannya melalui bahasa. Salah satunya tampak pada serat yang sarat kritik pada agama dan sejumlah anasir pada erotisme vulgar: Gatholoco. Terlepas dari perdebatan kontekstual politik keagamaan di masanya, serat ini, bahkan untuk konteks sekarang, masih memungkinkan sebuah arah baru. Terutama berkenaan dengan orientasi dan afirmasi pada tubuh-alih-alih dinegasi.
\end{abstract}

Kata Kunci:

Kritik; Tradisi; Modern; Bahasa; Tubuh; Mitos; Kebudayaan; Mistisisme.

\section{A. PENDAHULUAN}

Dalam tiap hal yang mapan, akan lazim ditemukan kritik. Demikian halnya juga dengan agama, dalam hal ini terlebih agama Islam. Jika kita hendak berkaca pada realitas, gerakan puritanisme yang kembali ke sumber asal ajaran Islam, bukan lagi berita baru. Fenomena macam itu akan banyak ditemui ketika agama bertemu dengan perubah, dalam hal ini realitas sosial. ${ }^{1}$

\footnotetext{
${ }^{1}$ Seyyed Hossein Nasr, seorang tradisionalis di era
} ini menegaskan bahwa paradoks pertentangan antara
Islam di Jawa, merupakan kajian yang sangat menarik untuk diteliti. Sampai saat ini tak henti-hentinya para pembaca, peneliti, pembahas terus-menerus mendiskusikan, menulis pada beberapa buku yang semuanya membahas masalah ini. Hal ini juga tidak ada

kemapanan agama dan realitas eksternal terletak pada kesukaran manusia menerima akar tradisi di satu sisi dan menampik sunnah-Nya atas masa depan dengan terjerumus pada fundamentalisme dan modernisme. Ia sendiri mencatat bahwa, -Islam tradisional berlawanan dengan fundamentalisme dan modernisme. Seyyed Hossein Nasr, Islam Tradisi; di tengah kancah Dunia Modern, Bandung: Pustaka, 1994, h. viii. 
bedanya dengan penulis untuk melakukan kajian Islam di Jawa, dalam hal ini akan diangkat kajian Islam dalam - Serat Gatholoco. Gatholoco merupakan karya yang kontraversial, sosok dan penamaanya mendorong orang untuk mengasosiasikan pada persoalanpersoalan yang berkonotasi jelek. Sebenarnya bukan hal jorok yang dikemukakan, akan tetapi bagaimana orang menilainya.

Dalam kasus keagamaan yang biasanya selalu susah, selain ada kritik, ada juga gugatan. Kritik biasanya datang dari arah internal, dan gugatan biasanya berasal dari luar. Terutama kritik terhadap agama. Dalam sejarah peradaban Islam sendiri sejarah kritik terhadap tubuh ajaran Islam diajukan dan menemukan dialektikanya baik dalam bentuk perdebatan kalam, fiqih, maupun filsafat. Tapi di antara semua itu, yang biasanya menjadi sasaran (baca: korban/kambing hitam) adalah kaum sufi dengan sufismenya yang secara historis bisa dikatakan eksil dari dunia luar dan umum. $^{2}$

Pasalnya adalah dalam sistem yang mapan, diperlukan sesuatu yang bisa dijadikan korban. Ini bisa kita lacak sejak dari Al-Hallaj ${ }^{3}$, bahkan sampai pada konteks Indonesia sebagaimana dialami oleh Seikh Siti Djenar. Ketidak sepahaman di antara kaum keagamaan yang cenderung eksoteris ${ }^{4}$ dengan para esoteris dimanfaatkan oleh penguasa untuk diolah menjadi kepentingannya dan dikonfrontasikan. ${ }^{5}$

${ }^{2}$ Lihat bagian mengenai historisitas ini lebih lanjut dalam Ensiklopedi Dunia Islam, Vol 4: Pemikiran dan Peradaban, Pt. Ikhtiar Baru Vanhouve: 2000. h. 139.

${ }^{3}$ Lihat bagian spesifik mengenai subjek ini dalam, Annemarie Schiemmel, Dimensi Mistik Dalam Islam, (ed. Sapardi Djoko Damono, et. al) Pustaka Firdaus: 2000, h. 16.

${ }^{4}$ Menurut kata asalnya di dalam KBBI eksoterik berarti: pengetahuan yang boleh diketahui atau dimengerti oleh siapa saja. Akan tetapi frasa ini biasa digunakan dalam kepustakaan dengan tema-tema mistisisme, yang mana rujukan keta bagi eksoterisme adalah zahir dan esoterisme biasa diasosiasikan sebagai batin. Sejatinya frasa-frasa ini hanya merupakan kemungkinan bahasawi. Untuk penelaahan lebih lanjut lihat Frithjof Schuon, Tasawuf: Proses Ritual Menyingkap Tabir Mencari Yang Inti, Srigunting: Jakarta, 2000, h. 25.

${ }^{5}$ Mengenai sifat kritik pada persoalan agama (yang
Sifat-sifat konfontatif yang terjadi di dalam pergolakan keagamaan memang identik dengan perdebatan sebagaimana diutarakan di atas. Tapi yang selanjutnya harus digaris bawahi adalah corak signifikansinya. Maksudnya, jika kita berangkat dari kritik dan titik ini, reaksi antara kedua belah pihak yang berkonfrontasi biasanya berbeda, sesuai dengan kecenderungan masing-masing. Tapi untuk kesempatan kali ini, penulis hendak mengetengahkan satu corak yang sifatnya ekstrim dari garis yang dituliskan merupakan garis spiritual. Yakni serat Gatholoco.

Dari latar belakang penciptaannya, semula sebagai media penyembahan dan pelaksanaan ajaran nenek moyang, untuk mengetahui asal usul manusia, maka diperlukan penyatuan lingga-yoni, sehingga terbentuklah manusia. Dan dari lingga-yoni pula manusia dilahirkan di dunia, atau dengan kata lain asal manusia itu dari bapak-embok (bapak dan ibu). ${ }^{6}$ Karena itu ada beberapa pandangan yang menilai bahwa serat ini sarat akan muatan tasawuf, tentang hakekat hidup, sangkan paraning dumadi, juga tentang Manunggaling Kawula lan Gusti. Karenanya, serat ini sempat dilarang peredarannya saat itu dan sampai sekarang pun masih terdapat perdebatan panjang guna membahas serat yang juga pernah dilarang oleh orde baru tersebut. Menurut Wawan Susetya dalam bukunya yang berjudul -Kontroversi Ajaran Kebatinan menyebutkan bahwa Serat Suluk Gatholoco ini memang sempat dilarang oleh orde baru, karena mengegerkan dalam konstelasi perpolitikan di tanah air, karena menyangkut perdebatan abadi antara kaum kebatinan dengan kaum santri. Dan, penggelembungan mengenai wacana "manunggaling kawula-

\footnotetext{
kemudian berkesinambungan dengan maksud pembahasan penulis) dapat diikuti dalam; Goenawan Mohamad, Catatan Pinggir, (dengan judul Gatholoco), Pusat Data dan Analisa Tempo: 2005. Saya kutipkan cuplikan GM mengenai subjek ini: -Tiap sistem keimanan akan didatangi seorang Gatholoco — sebuah sosok negatif. Dalam khazanah Islam di Jawa, nama tokoh ini berasal dari sebuah puisi naratif panjang yang kontroversial.

6 Joko Su'ud Sukahar, Tafsir Gatholoco, Yogyakarta, Narasi, 1999, vii.
} 
Gusti" saat itu memang menjadi polemik panjang; ada yang toleran dan ada pula yang mengharamkannya! Padahal, dalam konteks kebatinan dan tasawuf, wacana mengenai „,manunggaling kawula-Gusti" (ittihad, hulul) sangat dikenal di masyarakat Jawa; atau yang biasanya disebut dengan ,warangka manjing curiga, curiga manjing warangka" atau ,,mati sajroning urip, urip sajroning mati". ${ }^{7}$

\section{B. HASIL DAN PEMBAHASAN}

\section{Sejarah dan Signifikansi Serat Gatholoco}

Serat Gatholoco sendiri merupakan karya sastra Jawa anonim yang muncul pada awal abad 19 di jaman Mataram Surakarta. Isi teks menceritakan perbincangan atau perdebatan antara Gatholoco dengan Dewi Perjiwati mengenai hakikat pria-wanita, ${ }^{8}$ perilaku dalam asmaragama dan asal terjadinya benih manusia. Tokoh Gatholoco digambarkan sebagai seorang anak raja Suksmawisesa dari kerajaan Jajarginawe yang berparas jelek sekali. Ia mempunyai seorang hamba yang sangat setia, bernama Darmagandhul. ${ }^{9}$ Gatholoco disuruh belajar oleh bapanya agar ia memperoleh kawruh kasunyatan atau kini kita bisa mengatakannya sebagai Ilmu Sejati. ${ }^{10}$

Diceritakan tentang tiga orang guru mengaji, yaitu Abdul jabar, Abdul manab, Abdul gharib. Ketiganya amat fasih dalam membaca Al Quran, Fikih dan Nahwu. Mereka berjumpa dengan Gatholoco dalam perjalanan, terjadilah perdebatan antara ketiga guru mengaji tersebut dengan Gatholoco. Perdebatan meliputi tentang arti orang yang memiliki ilmu, haram, atau najis dan arti halal. Gatholoco memenangkan perdebatan dan akhirnya mengajak mereka berteka-teki.

Teka-teki Gatholoco antara lain mengenai wayang, dalang, blencong, dan kelir. Dari keempat itu manakah yang lebih tua? Perde-

7 Wawan Susetya, Kontroversi Ajaran Kebatinan, Yogyakarta, Narasi, 2007. 56.

8 Atau bisa dikatakan hakikat mengenai vitalitas

9 dalam arti luas merupakan kebajikan dan gandhul merupakan metafor bagi sesuatu yang menggantung.

${ }_{10}$ Bagian ini dikutip dan direproduksi ulang dari laman elektronik, heritageofjava.com batan dimenangkan oleh Gatholoco. Ia menerangkan juga tentang hakikat wayang, dalang, kelir, blencong dan gamelan. Ketiga guru mengaji itu akhirnya meninggalkan Gatholoco dan menuju Cepekan. Di Cepekan terdapat tiga orang guru mengaji, yaitu: Kasan Mustahal, Kasan Besari, dan Ki Duljalal.

Mereka ini didatangi oleh ketiga orang guru mengaji yang kalah berdebat dengan Gatholoco. Mereka menceritakan tentang kekalahan dalam perdebatan. Gatholoco dicari dan diajaknya ke Pondok Cepekan untuk diajak berdebat tentang ilmu sejati. Perdebatan antara Gatholoco dengan ketiga orang guru mengaji di Pondok Cepekan berlanjut. Akhirnya dimenangkan oleh Gatholoco, karena mereka kalah (ketiga guru mengaji), maka diusirlah Gatholoco dari pondok tersebut. Pada mulanya Gatholoco tidak mau pergi kalau tidak diberi uang. Akhirnya, ia meninggalkan pondok tersebut untuk melanjutkan pengembaraannya.

Perjalanan Gatholoco sampai di gunung Endragiri dan bertemu dengan seorang pertapa yang bernama Dewi Perjiwati yang didampingi oleh para emban dan cantriknya. Sebelum bertemu dengan Dewi Perjiwati terpaksa harus menghadapi para emban dan cantriknya yang mendampinginya. Para emban dan cantrik tersebut memberikan tekateki untuk dijawab oleh Gatholoco. Ternyata teka-teki yang diberikan dapat dijawab oleh Gatholoco dengan baik, kemudian Gatholoco dapat bertemu dengan Dewi Perjiwati, maka terjadilah tanya jawab. Pertanyaan yang diajukan oleh Dewi Perjiwati adalah tentang arti kalimah Syahadat, arti pria-wanita dan suaimi istri. Apabila Gatholoco dapat menebak dengan betul maka sebagai imbalannya adalah Dewi Perjiwati bersedia menjadi istrinya. Ternyata Gatholoco dapat memenangkan perdebatan tersebut sehingga Dewi Perjiwati terpaksa mau menjadi istri Gatholoco walaupun dengan berat hati. Para emban dan cantrik memberikan saran agar Gatholoco diajaknya masuk ke gua, setelah sampai di dalamnya maka pintu gua segera ditutup.

Darmagandhul, hamba setia Gatholoco memperingatkan tetapi tidak dihiraukan, ia 
mengalami pingsan di dalam gua. Setelah sampai di luar ia baru sadar bahwa telah terjebak oleh tipu Dewi Perjiwati. Karena merasa terjebak, maka Gatholoco merasa malu, akhirnya ia masuk kembali ingin berperang dengan Dewi Perjiwati. Keduanya ternyara sama-sama sakti dan tidak ada yang menyerah. Tidak lama kemudian lahirlah seorang bayi dari rahim Dewi Perjiwati, baik Dewi Perjiwati maupun Gatholoco sangat sayang melihat anak tersebut. Ia bertanya kepada Dewi Perjiwati, sebetulnya anak siapakah bayi itu? Dijawabnya. Ia adalah anak dari Gatholoco sendiri. Anak tersebut kelak diberi ajaran tentang rukun Islam.

Penggunaan lain terdapat aliran kebatinan yang menggunakan nama Gatholoco. Nama gatoloco juga digunakan sebagai nama kesenian rakyat daerah Kedu. ${ }^{11}$ Nama itu dipakai sebagai singkatan dari "digathuk-gathuke dadine lucu", memanfaatkan kepopuleran nama Gatoloco yang dipakai sebagai judul suluk populer ini. Kesenian ini tidak ada hubungan dengan suluk, kecuali kesamaan nama.

Pada Februari 1872, Carel Poensen, misionaris Belanda yang menghabiskan hampir 30 tahun di Kediri, Jawa Timur, mendiskusikan karya ini dengan beberapa asistennya, orang Jawa Kristen. Bagi Poensen, dari sudut pandang sastra, karya ini kurang berharga. Tapi menilik semangatnya, penulis karya itu menyodorkan konsepsi mengenai akhlak dan kebajikan, yang sayangnya tanpa kearifan dan kesopanan. Carel Poensen mencatat:

Bahkan ia kerapkali membuat kami muak, karena dia tak menahan diri dari melakukan hal-hal yang paling sepele untuk publikasi, dan dengan cara yang menjijikkan masuk ke detail tentang hal-hal yang tak layak disebutkan.

Poensen khawatir dengan dampaknya bagi pembaca. Selain vulgar, isinya mempermalukan umat Islam, orang-orang yang membawanya ke Jawa, dan — kaum putihan yang pada 1870-an meperkenalkan reformasi Islam. Dia pun berusaha agar karya itu tak menyebar ke

11 Kembalinya Gatoloco ke Bumi Magelang. Artikel Suara Merdeka online, diudarakan tahun 2007. mana-mana. Di tempat lain, Menurut Merle Calvin Ricklefs dalam Polarising Java Society: Islamic And The Other Visions 18301930, ada dua karya lainnya yang berkaitan dengan suluk ini dan juga mengajukan argumen anti-Islam: Babad Kedhiri dan Serat Dermangandhul. Ketiganya, muncul pada dekade tanda-tanda kebangkitan Islam di Jawa, menyebut konversi agama Jawa ke Islam sebagai kesalahan peradaban. Ricklefs memperkirakan, satu atau lebih priyayi di Kediri menyusun sebuah pandangan baru dan tak lazim mengenai Islamisasi di Jawa pada awal 1870-an.

Belum jelas benar siapa penulis Suluk Gatholoco dan kapan persisnya dikarang. Phillipus van Akkeren, misionaris di Jawa Timur, memperkirakan terbit pada 1830 yang isinya mencerminkan reaksi luas di kalangan kelas melek-huruf di Jawa atas kegagalan total kepemimpinan politik Islami Diponegoro. Tapi, GWJ Drewes, seorang orientalis Belanda, melihat kesamaan suluk itu dengan Serat Dermagandul dan Babad Kediri-yang menceritakan kejatuhan kerajaan -HinduBuddha Majapahit akibat koalisi Islam yang dipimpin Demak, sekitar 1878. Senada dengan Ricklefs, Benedict Anderson, seorang yang bisa dikatakan Indonesianis, berdasarkan deskripsi tentang madat di pedesaan Jawa yang tampaknya sesuai dengan keberadaan sistem pertanian-opium, memperkirakan tahun 1860 atau bahkan awal 1870-an.

Suluk Gatholoco beredar dalam bentuk naskah rapi pada 1883 dan kali pertama diterbitkan secara terbatas sebagai buku di Surabaya pada 1889. Ketika terbit, tak ada reaksi publik yang bermusuhan. Namun, respon tajam muncul ketika pada Januari 1918, surat kabar berbahasa Jawa Djawi Hiswara, organ Sarekat Islam cabang Surakarta, menerbitkan sebuah artikel yang memfitnah Nabi Muhammad sebagai pemabok dan pemadat, berdasarkan bagian dalam Suluk Gatholoco. Sejumlah aktivis Islam yang dipimpin HOS Tjokroaminoto meresponnya dengan membentuk Tentara Kangjeng Nabi Muhammad. 
Muncul pula kecaman dari pers pribumi, unjuk rasa di Surabaya dan 42 lokasi di seluruh Jawa, serta desakan agar pemerintah kolonial menuntut editor Martodharsono dan penulis artikel Djojodikoro. Tapi kontroversi itu kemudian mereda, digantikan isu lainnya, sebagaimana kini berita mudah beralih seiring beralihnya isu.

Sejak itu, Suluk Gatholoco beredar di bawah tanah (under ground). Tak ada penerbit yang mau ambil risiko menerbitkannya; kebanyakan takut dicap murtad atau penyebar pronografi. Baru pada 1951, Philippus van Akkeren menerbitkan teks utuh Suluk Gatholoco untuk kali pertama, lengkap dengan terjemahan dan analisisnya. Di bawah tajuk Een gedrocht en toch de volmaakte mens: A Monster, Yet the Perfect Man, diterbitkan Penerbit Excelsior di The Hague. Di Indonesia sendiri, setahun sebelumnya, terbit Gatholotjo oleh Tanaya (juga ditulis R. Tanojo). Kemudian muncul Balsafah Gatolotjo: Ngemot Balsafah Kawruh Kawaskitan karya Prawirataruna, diterbitkan Penerbit S. Mulija, Solo, pada 1958. Sejak 1963, berdasarkan UU No 4/PNPS/ 1963, pemerintah melarang Suluk Gatholoco. $^{12}$

\section{Sejarah Kelahiran Agama Djawa Sunda}

ISLAM memasuki Nusantara pada abad ke12 atau ke-13, bahkan di abad ke-13 diperkirakan bahwa Islam telah memasuki tanah Jawa. ${ }^{13}$ Di saat hegemoni penyebaran agama Islam pada abad 19 ke pedalaman yang intensif dan teratur membuat masyarakat pedalaman yang sebelumnya telah mengenal agama Hindu-Budha dan telah diwarisi oleh nenek moyang mereka keyakinan terhadap animisme dan dinamisme yang kemudian menjadi kepercayaan asli mereka.

Ada unsur kebudayaan di dalamnya. Sinkretisme yang mencampurkan antara unsur Islam dan Hindu-Budha yang saat itu masih kental, sekarang kita mengenalnya dengan

12 Pada bagian mengenai dinamika ini penulis menggunakan bahan yang diambil dari redaksi historia.co.id, dengan tajuk artikel Kitab Lelaki Sejati.

13 Graaf dan Pigeaud. Kerajaan-Kerajaan Islam Di Jawa: Peralihan Dari Majapahit Ke Mataram. Ed. Soemarsaid Moertono. 1983. agama Jawa. ${ }^{14}$ Merasa terdesak dengan penyebaran agama Islam karena adanya benturan budaya di titik ini serat Gatholoco bisa dikatakan merupakan bentuk pemberontakan yang dilakukan oleh para pujangga dan paham Kejawen terhadap Islam di tanah Jawa. Hal ini didukung oleh pendapat Dr. Suyatno Kartodirjo di masa-masa penyebaran agama Islam, kesusastraan juga mengalami masa keemasan. ${ }^{15}$

Dalam serat tersebut banyak sekali istilahistilah yang digunakan dalam dunia Islam sebagai perbandingan dengan ajaran Kejawen yang dianut oleh Gatholoco. Selain itu yang menjadi kontroversi lainya adalah penggunaan bahasanya yang jorok dan kasar. Menurut pendapat Djoko Adi Waluyo, pengunaan bahasa yang jorok dan kasar sebagai salah satu daya tarik pembaca untuk membaca serat ini, selain itu alasan lainnya agar dapat tersebar luas dengan cepat. ${ }^{16}$ Pendapat lain, Farid Mustofa, mengatakan pengunaan kata bagian-bagian alat reproduksi manusia (alat kelamin dan seks) dimaksudkan agar penyampaiannya lebih komunikatif. ${ }^{17}$

Hingga pada masa Orde Baru serat Gatholoco sempat dicekal peredarannya, karena dianggap dapat merusak agama Islam. Emha Ainun Nadjib mengemukakan alasan mengenai pelarangan serat Gatholoco oleh pemerintah saat itu. Alasannya karena di Indonesia masyarakat mayoritas beragama Islam, sementara serat itu tidak disukai oleh mereka. Pemerintah khawatir serat tersebut akan menimbulkan reaksi kemarahan yang meluas. ${ }^{18}$

Gatholoco memiliki makna di balik namanya, secara keseluruhan Gatholoco yang berarti alat kelamin laki-laki. —Gatho berarti -kepala, sedangkan -Loco berarti —alat gosok. Ia menganggap dirinya sebagai lelanange jagad. Gatholoto memiliki dua nama lain yaitu, Barangkinisik, dan Barangpanglusan. ${ }^{19}$

\footnotetext{
14 Muchtarom Zaini, Santri dan Abangan di Jawa. 1988, h. 6.

${ }^{15}$ Joko Su'ud Sukahar, Tafsir Gatholoco, h. 98

${ }^{16}$ Ibid., h. 117

17 Ibid., h. 105

${ }^{18}$ Ibid., h. 138.

${ }^{19}$ Ibid., h. 17.
} 
Ketika Gatholoco beradu ilmu agama dengan lawannya, salah satu cara yang ia lakukan untuk melawan argumen lawannya adalah, dengan cara mengajukan cangkriman, begitu pula dengan lawannya yang juga mengunakan cangkriman sebagai sarana dialog di antara mereka.

Cangkriman dalam serat ini digunakan sebagai sarana dialog antar tokoh dengan tujuan beradu ilmu pengetahuan. Persoalan di dalam cangkriman berupa susunan kalimat yang mengambarkan situasi dan kondisi dari konsep kosmologi dan kosmogoni yang dijelaskan secara abstrak. ${ }^{20}$

Tidak sembarangan cangkriman yang dibuat oleh Gatholoco, karena sosok Gatholoco adalah sosok seorang yang mewakili dirinya sebagai pribadi Jawa yang religius. Religius diartikan sebagai suatu ketaatan, saleh, pada suatu agama, dan terkesan dengan adanya kehidupan yang ada di Indonesia. ${ }^{21}$ Dalam serat ini diceritakan bahwa Gatholoco sebagai sosok yang banyak mengetahui ilmu agama Islam, tetapi ia tidak menjalankannya sama sekali.

Gatholoco hanya sebatas memahaminya, terbukti dari kelakuannya yang menentang semua jenis peraturan-peraturan yang ada di Islam. Begitu pula dengan cangkriman yang dibuat oleh kelima istrinya. Gatholoco sebagai sosok perwakilan dari kejawen yang lebih mementingkan rasa. Rasa yang dimaksud adalah batin lebih unggul daripada yang lahir, rasa lebih dari yang rasio, yang halus lebih dari yang kasar. ${ }^{22}$

Gatholoco sebagai sosok yang memiliki sifat yang sulit ditebak atau berubah-ubah, diceritakan bahwa ia terkadang bisa berperilaku tidak sopan sehingga membuat kesal orang yang sedang berhadapan dengannya dan bahkan bisa sangat sopan apabila ia sedang menghisap madat, karena membuat ia dapat mengendalikan perasaan dari lawan yang sedang berhadapan dengannya.

${ }^{20} \mathrm{KBBI}$. Abstrak adalah tidak berwujud dan tidak berbentuk. h. 3 .

${ }^{21}$ Joko Su'ud Sukahar, Tafsir Gatholoco, h. 739.

${ }^{22}$ Niels Mulder, Kebatinan dan Hidup Sehari-hari Orang Jawa. 1984, h. 114.
Biasanya terlebih dahulu Gatholoco memancing emosi lawannya agar pikiran dari lawannya dapat dibuat terombang-ambing oleh Gatholoco, setelah itu Gatholoco dapat menguasai pikiran dari lawannya. Kekuatan pemikiran atau daya pikir dapat dibagi ke dalam kekuatan terpendam, kekuatan rahasia, dan kemampuan dari kemauaan, semua kekuatan tersebut sebagai kekuatan jiwa. Dengan kata lain Gatholoco adalah sosok jiwa tersebut, hal itu tersirat dari pemikiranpemikiranya yang ia sampaikan melalui cangkriman.

Cangkriman selain digunakan sebagai sarana dialog juga berfungsi sebagai sebagai sarana dalam menyampaikan pemikiran-pemikiran filosofis setiap tokoh yang berdebat mengenai ilmu pengetahuan. Dialog terjadi ketika mereka saling mempertahankan keyakinan mereka masing-masing. Saat lawan tandingnya memberi cangkriman sesulit apapun, Gatholoco seakan-akan memiliki seribu satu kata untuk menjawabnya. Namun ketika Gatholoco sendiri yang memberikan cangkriman tersebut, hampir tidak ada lawan tanding yang bisa menjawab cangkriman dengan benar.

Sekalipun Gatholoco telah menjawab setiap cangkriman yang diberikan maupun dibuatnya sendiri, kita belum tahu persis pemaknaan yang sebenarnya, karena jawaban yang diberikan pun masih berupa falsafah. Bila kita mengamati cangkriman yang dibuat oleh Gatholoco maupun yang dijawab oleh Gatholoto, kata-kata yang digunakan terasa tidak biasa ditelinga kita, bahkan terkesan aneh. Adapun cangkriman dibuat sedemikian rupa agar adanya kekhasan. Kekhasan yang ingin membuat suatu kebingungan, terkadang lucu, dan bahkan menimbulkan kekacauan dalam merumuskan jawabannya. ${ }^{23}$

Sebagai sosok yang terkesan tidak mengerti aturan agama khususnya yang lebih banyak dibahas di serat tersebut adalah agama Islam. Gatholoco sering sekali diremehkan oleh lawannya karena bentuk fisik dan penampilannya yang kumuh. Ketika lawannya sudah menyinggung bentuk luar atau fisik dan

\footnotetext{
${ }^{23}$ Renggo Astuti, 1992-1993. Cangkriman. h. 15.
} 
tubuhnya, maka Gatholoco akan mengeluarkan pemikiran-pemikirannya yang intinya tidak memperdulikan wadhag. ${ }^{24}$ Tidak jarang ia mengunakan cangkriman sebagai senjata andalannya untuk mengungkapkan pemikiranpemikirannya yang menyinggung hal tersebut.

Sebagai manusia biasa, Gatholoco juga merasa tersinggung apabila ada yang mengolok-olok penampilannya yang kumuh, di saat terhina seperti itulah nalarnya berpikir untuk menghadapi pemahaman dari orangorang yang mengolok-oloknya. Di dalam serat Gatholoco gubahan R. Tanojo, terdapat enam cangkriman yang melibatkan Gatholoco (tokoh utama) sebagai pemberi dan penjawab cangkriman, begitu pula dengan tokoh bawahan lainnya yang memberikan cangkriman kepada Gatholoco. Keenam cangkriman tersebut mempermasalahkan persoalan kosmologi dan kosmogoni.

Banyak pertanyaan-pertanyaan mendasar mengenai kosmologi dan kosmogoni tersebut yang terangkum dalam enam cangkriman tersebut. Gatholoco sebagai tokoh dari nalar dan sosok gambaran jiwa yang selalu mampu menjawab semua cangkriman dengan baik dan benar. Salah satu unsur yang menjadi dasar di dalam mitologi Jawa adalah adanya ungkapan sangkan paraning dumadi, yaitu mendasari berbagai pertanyaan mendasar mengenai asal usul alam berserta isinya.

Seperti salah satu ungkapan orang Jawa di atas, dalam kebudayaan Jawa masih banyak lagi ungkapan-ungkapan yang di dalamnya terdapat mitos-mitos yang dapat mempengaruhi pola pikir masyarakatnya. Berikut tiga fungsi dan mitos menurut Van Peursen. Fungsi pertama, mitos adalah sebagai sebuah cerita yang memberikan pedoman dan arah tertentu kepada sekelompok orang. ${ }^{25}$

Cerita dari Gatholoco ini ingin menyampaikan makna-makna maupun amanat yang terkandung dalam falsafah hidup orang Jawa.

24 Bausastra lawa. Wadhag adalah raga atau badan. h. 835 .

${ }^{25}$ Van Peursen, Strategi Kebudayaan. 1988, h. 39. Bandingkan dengan pemaparan Mircea Eliade, Sakral dan Profan: Menyingkap hakikat Agama. (Inggris: The Sacred and The Profane), Fajar Pustaka Baru: Yogyakarta, 2002, h. 2.
Fungsi kedua, mitos adalah pemberi jaminan bagi masa kini. Dengan adanya pengetahuan tentang ilmu kosmologi dan kosmogoni yang sama dengan ilmu astronomi yang tentunya masih diterapkan sampai sekarang, mitos tersebut dapat dijadikan jaminan atau bekal untuk masa sekarang yang tentunya masih sesuai ketika diterapakan, bahkan dapat dijadikan sebagai sumber data pengetahuan.

Perihal di atas berkaitan dengan adanya fungsi ketiga dari mitos yaitu, mitos berfungsi sebagai pengantar antara manusia dan dayadaya kekuatan alam. ${ }^{26}$ Hal-hal gaib tidak begitu mudah dipahami tanpa adanya rasa yang peka terhadap alam, Gatholoco diceritakan dapat menjawab keseluruhan dan cangkriman yang di dalamnya terkandung masalah kosmologi dan kosmologi karena is paham akan filsafat kejawen atau ilmu rasa.

Tokoh Gatholoco ingin membuktikan kebenarannya. Kebenaran yang samar atau tidak jelas, hal tersebut dapat diperjelas salah satu caranya dengan membuat mitos. Tidak semua orang dapat memahami hal-hal gaib yang ada di dunia ini, sehingga manusia hanya dapat memepertanyakannya saja. Di dunia ini kita sebagai manusia masih banyak rasa keingintahuan yang timbul dari pertanyaanpertanyaan, sehingga membuat mitos-mitos di dalam alam bawah.

\section{Ke Arah Afirmasi Tubuh}

Di atas persoalan bentuk argumen yang ia kemukakan dalam mendebat lawan bicaranya, yang menarik adalah simbolisme di dalam serat ini yang hampir seluruhnya marupakan asosiasi dari pribahasa Jawa di atas. Selain itu yang paling menarik dari serat ini adalah sikapnya yang kukuh mengafirmasi tubuh. ${ }^{27}$

Bisa jadi, jika dilacak secara antropologis, jenis serat ini memang merupakan representasi dari keadaan pengarangnya yang anonim tersebut. Kita tahu, bahwa yang melatari terbentuknya sebuah karya sastra adalah kebudayaan (dalam hal ini struktur sosial pada

${ }^{26}$ Ibid., h. 41.

27 Studi lebih lanjut mengenai Tubuh dan kebudayaan dan bahasa dalam kaitannya dengan kekuasaan bisa didapat dari Michael Foucault, Ingin Tahu Sejarah Seksualitas, YOI: Yogyakarta, 2007. 
saat itu) dan selanjutnya atmosfer ajaran yang sedang menggejala (dalam hal ini ideologi tertentu) ${ }^{28}$ Dari asumsi yang ditarik tersebut, bisa terlihat misalnya kecenderungan vulgar yang tertera di dalam tubuh serat Gatholoco ini.

Bisa diasumsikan pula penulis merupakan seorang pujangga di satu sisi, tapi juga yang pola lingkungannya memungkinkan pikirannya dapat dituangkan dalam bentuk yang erotik dan sarkas. Ini bisa dilacak misalnya, jika serat ini ditulis pada masa kerajaan Mataram (menjelang kurun akhir) yang juga sudah diwarnai dengan ajaran Islam, dari kecenderungan serat sejenis pada kurun waktu yang juga tak jauh dari terbitnya serat Gatholoco ini.

Sayangnya, sebagaimana diungkapkan di atas-dan juga merupakan hasil risetmenunjukkan bahwa identifikasi serupa kurang memungkinkan terlacak. Tapi jika tipologinya kita sebandingkan dengan zaman Ronggowarsito, baik itu Ronggowarsito I, II dan yang terakhir menulis Zaman Edan, Ronggowarsito III, menunjukan kecenderungan yang lain sejak dari komposisi diksi dan bagaimana sebuah perdebatan disajikan dalam bentuk serat. ${ }^{29}$

Bahkan Buyutnya Ronggowarsito yang merupakan pujangga berpengaruh penulis Serat Dewa Ruci, mempunyai komposisi natratif yang benar-benar berlainan. Bisa jadi, pengaruh kevulgaran dan afirmasi pengarang Gatholoco pada tubuh berangkat dari semacam kecenderungan disorder yang secara sesiologis tak berada di lingkungan kerajaan.

Jika dibuat semacam peta sosial, ada perbedaan yang mendasar antara karya sastra gubahan orang-orang yang berada di lingkungan kerajaan dengan yang di luar. Sebagaimana penelitian Geertz menyatakan bahwa ada sistem kasta dalam sosiologi-antropologi orang Jawa yang telah mengakar dan membudaya.

28 Nyoman Kutha R, Antropologi Sastra; peran unsur-unsur kebudayaan dalam proses kreatif, Pustaka Pelajar: Yogya, 2011, h. 28.

${ }^{29}$ Lihat ulasan mengenai periodisasi penulisan karya sastra dari garis Ronggowarsito, Zaman Edan, 2002, h. 95.
Sehingga ada distingsi yang membedakan tipologi karya sastra. Sebagaimana kini juga terjadi, karya sastra memiliki orientasi bebas. jika seorang sastrawan berdekatan dengan struktur politik, karya sastranya akan terpengaruhi politik dan bagi yang berada di luar lingkaran ini biasanya bernada sengit dan menyerang.

Sikapnya yang afirmatif pada tubuh menuai kecaman karena ada dua ambivalensi sedang disejajarkan. Pertama, masyarakat awam, bahkan juga para intelektual menganggap bahwa ajaran Islam adalah luhur, benilai etika tinggi dan menjaga batas-batas. Dalam hal ini, memang bukan berarti bahwa ajaran Islam tak mengafirmasi wilayah privat dan vulgar; karena jika ini tak dibicaran tak mungkin dalam khazanah intelektual, dalam hal ini fiqih, bisa merumuskan mana yang baik berkenaan dengan alat kelamin dan persenggamaan.

Bukan berarti juga tabu dalam pembicaraan para sarjanwan muslim, yang jadi soal adalah jika ia digunakan dalam komunikasi lingual dalam arti yang sesungguhnya sebagaimana yang direpresentasikan oleh serat Gatholoco. Kedua, tendensi destruktif terasa sejak dari awal narasi karya sastra ini karena ada asosiasi lingusitik dan semiotis atas nama Gatholoco. Ketika diungkapkan bahwa arti namanya adalah-kepala (penis) yang -diloco (dikocok), maka dengan segera kita merujuk pada alat vital, penis lengkap dengan bagaimana dengan cara ia digunakan.

Porno, dalam kajian cultural studies, adalah memaksudkan sesuatu sebagaimana adanya. Ada ketelanjangan yang disengaja dari yang tadinya disamarkan. Dalam pembacaan ini, serat Gatholoco tak bisa lepas dari maksud dan tujuan pengarang. Sebagaimana dikemukakan dalam bagian signifikasni serat Gatholoco di atas, tercium bahwa serat ini dituli dengan gaya vulgar dan sarkas supaya ia bisa diterima secara luas dan menyebar dengan segera. Dalam hal ini, kesengajaan telah terjadi dalam penulisan karya ini.

Di titik ini, penulis menunda pretensi ke arah mana pun. Tapi yang jelas, sebagaimana tergambar dalam sinopsis, serat Gatholoco ini memuat sebuah agenda. Para peneliti kiranya 
tak dapat melacak agendanya sejauh hanya interpretasi teks tertutup dengan pembacaan hermeneutis. ${ }^{30}$ Karenanya kita harus menggunakan kacamata yang lebih plastis dalam menghadapi teks ini. Selanjutnya saya akan menggunakan Derrida dalam mengulas serat Gatholoco.

\section{Dari Fenomenologi ke Gramatologi lalu Ke Liturgi Tubuh}

Mari kita dekati teks Gatholoco dengan kacamata Derrida yang mana ia berangkat dari persoalan teks. Baginya, teks sendiri sudah merupakan realitas, diluar realitas eksternal itu sendiri. ${ }^{31}$ Teks dan bahasa, menurutnya juga selalu bertaut dengan hal-hal yang baru dan di luar persepsi juga konklusi kita mengenai keterpautannya dengan yang transenden dan baku. Hal ini menarik terutama karena nadanya orang interpretasikan sebagai suara nihilistis. Tapi ia cukup beralasan mengingat bahwa kehidupan banyak orang berangkat dari sebuah pemahaman mengenai teks. Bagi Derrida keudukan teks setara dengan Ada yang ontologis. Teks sekaligus adalah rumah sang ada, begitu kira-kira Derrida mengadaptasi pikiran Heidegger selanjutnya. Adagium -bahasa adalah rumah sang ada, seperti diungkapkan di muka adalah semacam pengingat bahwa realitas ontologis sejatinya selalu inhern dan kita alami. Tapi pengelaman manusia selalu luput dalam merasakan realitas itu. Demikian karena orang-orang terlampau dilenakan rasionalitas yang baku dan telah selesai. Kita ingat bahwa suara Derrida mewakili semangat posmodernisme.

Dalah Gatholoco kita temukan adanya semangat mengembalikan yang tabu dan kaku ke keluesan. Maksud kami, otoritas agamadalam hal ini Islam - pada masa itu menggambarkan suatu kekakuan. Pada gilirannya

30 C. Jenks, Culture, Pustaka Pelajar: Yogya, 2013, h. 62.

31 Segala sesuatu yang ada merupakan teks. Segala sesuatu yang ada ditandai tekstualitas. Tidak ada hors-text, kata Derrida tidak ada sesuatu di luar teks. Dan jika fenomenologi dulu asyik berbicara intersubyektivitas, maka Derrida sekarang berbicara tentang intertekstualitas, karena suatu teks tak pernah terisolir tetapi selalu berkaitan dengan teksteks lain. Filsafat Barat Abad XX, h. 496. prilaku beragama yang kaku dan rigid tidak bisa mewadahi proses kehidupan yang dalam skema kosmologi Jawa penuh dengan spontanitas. Pada dasarnya watak manusia adalah bebas dan tak hendak dikekang: karenanya ketika agama merepresentasikan kerangkeng tertentu, manusia selalu haus akan fitrahnya yang penuh dengan spontanitas.

Di dalam dunia modern yang termekanikkan, filsafat memang tak dapat lagi adaptif pada realitas sebagaimana adanya, tapi tidak bagi kultur Jawa. Filsafat memang kini bahkan sudah diambil alih oleh pragmatisme dan positivisme. Jangan dulu kita bicarakan iman dan hal-hal yang transenden, karena bahkan pada hidupnya sendiri yang banal, manusia kini semakin hilang aspek-aspek penghayatannya. Ia, sebagaimana dikhawatirkan Husserl juga heidegger, larut dalam kolam keseharian. ${ }^{32}$ Sialnya keseharian yang kita diami adalah keseharian bentukan dari sebuah agenda dan struktur. Karenanya jika kita menggunakan Derrida, kita bisa mengembalikan makna asali tiap kata dan teks pada pertautan tanpa tanpa batas bentuk. Kita belum sampai pada pemaknaan yang dihasilkan pertautan antar-teks di dalam Gatholoco. Karena pembacaan Derrida atas teks selalu menggunakan idiom baru dan cenderung muskil dipahami, pada saat itu pulalah ia sedang menunjukkan pada pembacanya dan juga khalayak akan relativitas makna. Berkenaan dengan sikap nyaman manusia terutama pada kondisi dalam Gatholoco terhadap realitanya, agaknya Derrida juga akan mengajukan semcam kritik tanpa kahir pada tiap hal yang ditemui.

Orang-orang hendak dibangunkannya dari tidur panjang akan definisi-definisi yang final (fixed) dan pada saat yang sama mengobarkan semangat dekonstruksi-termasuk dalam soal

${ }^{32} \mathrm{~F}$. Budihardiman mengupayakan pembacaan yang jernih terhadap realitas yang sedang diidap manusia moren saat ini dengan kembali pada tradisi Husserl dan heidegger. Tujuannya tentu saja agar kita bisa menghayati dengan penuh pengalaman kehidupan sehari-hari dengan transparan dan pada gilirannya menyingkapkan dirinya sebagaimana adanya (Aletheia). Mistik Keseharian, h. 43-58 
keagamaan. Dan sejauh berbicara mengenai dekonstruksi, maka di sana pula ada differance. Serangkaian istilah inilah yang erat sekali dengan sistem filsafat Derrida. Dalam dekonstruksi, ia mengajukan keterpautan kata pada kata asalainya. Di titik inilah kita akan berangkat dari fenomenologi ke gramatologi.

Jika filsafat, meminjam bahasa K. Bertens, sampai sekarang sama dengan logologi, maka Derrida ingin merubahnya menjadi — gramatologi. Yakni ilmu tentang gramma, hurufhuruf, inkripsi, tulisan. Gramma, adalah -tanda dari tanda, atau tanda yang menunjuk kepada tanda lain. Maka dari itu dapat diaktakan juga bahwa gramatologi adalah ilmu tentang tekstualitas. ${ }^{33}$

Serangkaian epistemologi Derrida atas apa yang diaktakan sebagai dekonstruksi, tentu saja belum lengkap tanpa mengetengahkan differance sebagai basis epistemik. Persis di sini ia sedang bermain dengan teks. Kata differance sendiri takkan bisa ditemukan dalam bahasa Francis. Tentu saja kata ini juga berbeda dengan different dalam bahasa Inggris yang artinya membedakan, berbeda, tidak sama dan berlainan. Tapi paling tidak apa yang hendak dikatakan Derrida dengan kata differance adalah sebuah upaya mensubstantifkan kata kerja differer dari menundamenangguhkan dengan bertolak belakang dan berbeda. Singkatnya apa yang hendak diajukan Derrida tidak jauh berbeda dengan apa yang diajukan Husserl dengan kata epoche. Keduaduanya mempunyai makna asosiatif yang kuat sebagai sebuah cara kerja pikiran yang menangguhkan segala sesuatu dalam memberikan definisi dan memberikan peluang bagi realitas itu tampak sebagaimana adanya. ${ }^{34}$

Cara kerja mengenai Differance terdiri dari empat bagian; pertama-tama, menunjuk kepada apa yang menunda kehadiran. Differance adalah proses penundaan yang aktif sekaligus aktif secara bersamaan, yang tidak didahului oleh kesatuan asali. Selanjutnya, Differance adalah gerak yang mendiferensiasikan. Dalam arti ini Differance adalah akar bersama bagi semua oposisi antara konsep-

\footnotetext{
${ }^{33}$ Filsafat Barat Abad XX, h. 498.

${ }^{34}$ Gayatri. C. Spivak, h. 99.
}

konsep seperti misalnya inderawi- rasional, intuisi-representasi, alam-dan kultur. Ketiga, Differance adalah produksi semua perbedaan yang merupakan syarat untuk timbulnya setiap makna dan setiap struktur. Perbedaan-perbedaan ini merupakan hasil dari sebuah differance. Sekaligus pada bagian ini Derrida hampir senada dengan Saussure. Dan yang terakhir, differance dapat juga menunjukkan juga berlangsungnya perbedaan Ada dengan Adaan, suatu gerakan yang belum selesai. Jadi, arti yang keempat ini sangat erat dengan Heidegger sekaligus masuk dalam differance itu sendiri. ${ }^{35}$

Tapi differance tak bisa juga kita masukkan dalam sebuah pengertian bahwa itu merupakan sebuah anasir yang jika kita telusuri akan bertaut dengan kebenaran yang transenden (signifie trancendental) seperti halnya Tuhan, Yang Absolut, Roh, Materi atau asal-usul kebenaran lainnya. Dengan kata lain, meminjam Bertens, adanya tekstualitas tidak mengizinkan untuk menganggap perbedaan-perbedaan tidak mungkin diatasi dan disintesakan dalam suatu identitas terakhir. ${ }^{36}$

Tapi bagaimana jadinya jika skema cacahan Derrida akan realitas sebagai teks dipakai untuk membaca naskah-naskah yang bernapaskan azali, baku, formal dan sakral seperti kitab suci? $?^{37}$ Atau dipakai mendedah serat Gatholoco yang dalam hal ini memuat unsur religius, mitos yang sarat sastra. Tapi sebelum masuk lebih dalam pada kemungkinan interpretasi dan aplikasi skema Derrida pada realitas teks Gatholoco, mari kita sejenak merenungi realitas faktual hari ini.

Sejauh bisa diamati, realitas kita hari ini begitu sibuk, padat dengan waktu merayap

\footnotetext{
${ }^{35}$ Filsafat Barat Abad XX, h. 502

36 Derrida berusaha mamahami tanda sebagai trace (bekas). Yang penting di sini adalah bahwa sebuah bekas tidak mempunyai substansi atau bobot tersendiri; tapi hanya menunjuk. Bekas tidak dapat dimengerti tersendiri (terisolir dari segala sesuatu yang lain), tetapi hanya sejauh menunjuk kepada al-hal lain. Bekas mendahului objek. Bekas itu sebetulnya bukan efek, melainkan terutama penyebab, kata Derrida, Filsafat Barat Abad XX, h. 495.

${ }^{37}$ Derrida menolak pembedaan antara tanda dan simbol; suatu pembedaan yang sering dikemukakan dalam tradisi. Menurut para pendukungnya, simbol mempunyai hubungan natural dengan apa yang ditunjukkannya, sedangkan tanda tidak menunjukkan hubungan serupa itu atau-dengan perkataan lainbersifat arbitrer belaka. Filsafat Barat Abad XX, h. 497.
} 
bergegas ke lenyap tanpa bisa kita fahami dan atau bahkan kita nikmati. Banyak orang atau mungkin di antara kita yang kepepet merasa kehabisan waktu dan hidup tak lebih dari sekadar pakansi dari parodi ke parodi. Bukan untuk melebih-lebihkan, tapi pada kenyatannya realitas modern-posmodern inilah yang sedang berjangkit pada banyak orang; dimana banalitas dirayakan dan relativitas adalah bahkan Tuhan itu sendiri. Bagaimana tidak, bahkan pada satu sistem agama sekalipun terasa bahwa yang sedang bergerak bukan semata Yang Ilahi; tapi juga ihwal yang bangsat.

Posmodernisme seperti digambarkan di atas sebenarnya bukan posmodernisme yang digadang-gadang merupakan napas baru bagi sebuah tatanan hidup yang anti mapan. Justru kemapanan paradoksallah yang sedang terjadi Ambivalensi iniah yang mendorong Nietzsche, sejak permulaan abad silam mengarahkan manusia pada sampan nihilisme. ${ }^{38}$ Karena di dalam apa yang dinamakan dengan sistem agama hanya menjadikan manusia budak dan tidak meningratkan manusia.

Awal posmodernisme ditandai oleh satu prasangka dalam diri agama. Karenanya Tuhan dalam diskursus ini ditunda; jika tidak dikatakan Dibunuh. ${ }^{39}$ Bagai mana tidak, ketimpangan hidup dan kemelorotan nilai kemanusiaan pada saat itu sangat kuat dan gampai ditemui. Seakan-akan agama hanya candu dan semacam pelarian bagi para pesakitan neurotik yang mengangankan kehidupan surgawi dan abai pada realitas yang sedang ia alami.

Pada gilirannya, karena manusia selalu dirundung duka, tema-tema mengenai theodise mencuat dan digantikan iman pada nihilisme. Tuhan rupanya berkarat, melapuk dan manusia hendak mengambil alih. Pertanyaannya berhasilkah? Jawabnya ya dan tidak. Ya

\footnotetext{
${ }^{38}$ Pada bagian ini perlu disampaikan bahwa Derrida juga diidentifikasi sebagai pembawa faham nihilisdisamping bahwa ia juga terpengaruh oleh Nietzsche, Sigmund Freud, dan juga Levinas. Filsafat Barat Abad XX, h. 501.

39 Lihat misalnya Para Pembunuh Tuhan, A. Setyowibowo, Para Pembunuh Tuhan, Yogyakarta: Kanisius, 2009, h. 19.
}

karena manusia, pada saat ini bisa dikatakan sangat bahagia dengan kehendak bebasnya sekaligus tidak karena rupanya manusia juga semacam rem blong. Inilah jagat yang ditinggalkan Derrida dan yang seharusnya dirapikan oleh dekonstruksinya. Tapi terlepas dari ini semua, aplikasi dekonstruksi Derrida bisa dipakai dalam meluruskan kesalah mengertian manusia pada kebebasan.

Yang menarik bagi penulis adalah bahwa jika memang dengan teori dekonstruksi kemapanan sebuah institusi agama terancam, maka sudah seharusnya agama merehabilitas diri. ${ }^{40}$ Pasalnya, yang terjadi justru-jika memang terjadi dekosntruksi-orang-orang lupa bahwa bahwa setelah bengunan dirubuhkan ia seharusnya mencari makna baru atau jika perlu membangun lagi. Sialnya, sejauh yang penulis amati, setelah iman dan bangunan yang mantap dirubuhkan, orang justru frustasi dengan menertawakan keruntuhan itu. Hal ini senada dengan ramalan Marc Goldschmit yang bertutur;-tanpa bisa menertawakan diri sendiri, dekonstruksi tidak akan mungkin terwujud. ${ }^{41}$ Tesis ini bisa diterima sebagai kelanjutan dari sebuah nada nihilisme. Persoalan kemudian bagaimana dengan kutub moral yang kadung terdiktekan oleh kitab suci. Di titik ini kita masuk pada penelaahan gramatologi ala Derrida.

Menurut interpretasi Bambang Sugiharto, agama-agama melakukan imunisasi pada dirinya sendiri. Agama-agama terutama Abrahamik-Semitik dengan jelas melakukan imunisasi ini. $^{42}$ Maksudnya adalah, agama pada tataran praktis menginternalisasi diri dengan benteng dogmatisme. Ia menolak dialektika dan atau dialog dengan terbuka: bahkan dengan sesama agama itu sendiri. Akhirnya agama-agama ini asyik dengan dirinya sendiri tanpa melihat dengan seksama bahwa di dalam teks suci mereka Tuhan sedang berdialektika. Ini satu kejahatan kemanusiaan mengingat bahwa tugas agama

${ }^{40}$ Bandingkan dengan pemaparan Haryatmoko mengenai subjek yang hampir serupa dalam Basis, 2007, h. 4.

${ }^{41}$ Dikutip dari tulisan panjang Haryatmoko, Ibid., h.4.

${ }^{42}$ Ibid., h. 30 
dan wahyu adalah membebaskan dan bukannya saling berkonfrontasi.

Maka moralitas lari pada individu, seperti halnya juga kebenaran dan interpretasi teks suci. Memang seakan akan paradoksal jika ditautkan dengan agama. Tapi pasalnya, bukankah di dalam teks suci tersebut juga temaktub sejumlah hal yang paradoks. Tuhan sendiri misalnya; di satu sisi ia menampakkan diri sebagai asih dan di sisi lain ia berwajah muram.

Persis di sini dekonstruksi memberikan kemungkinan antar agama sebagai sebuah rumah yang terbuka bagi tamu (yang liyan). Kesemuanya, manusia, agama dan sistem apa pun pada gilirannya-jika kita terapkan dekonstruksi-akan menjadi semacam pengingat bahwa pada tiap hal itu tertanam kerentanan. ${ }^{43}$ Sistem ini, sebagaimana diterangkan Bambang Sugiharto, baik tuan rumah maupun tamu, dalam ketidak pastian, keduanya bisa bertukar posisi, dan identitas keduanya bisa menjadi rapuh, saling dibongkar dan dibentuk ulang, saling didefinisikan kembali secara baru, oleh yang lainnya. ${ }^{44}$

Selanjutnya, meski interpretasi Derrida pada teks yang pada gilirannya mengarah pada agama tidak terlalu mendalam dan tak juga bisa dikatakan sistematis, paling tidak ia memberikan andil pada dialektika itu sendiri. Maksudnya adalah bahwa dengan satu skema dekosntruksi, khalayak diajak untuk menjejaki kemungkinan-kemungkinan baru. Kadang, mungkin dalam perjalanan itu kita menemukan yang tak terpermanai dan kita terkagumkagum.

Tapi memang, seperti halnya Alitheia ${ }^{45}$, dengan differance ${ }^{46}$, kita bisa bertemu dengan

${ }^{43}$ Bambang Sugiharto Kalam, 1995, h. 31.

${ }^{44}$ Ibid., h. 31.

${ }^{45}$ Alitheia adalah sebuah penyingkapan realitas sekelebat. Penulis selalu menyamakan ketersingkapan ini dengan bahasa dalam kajian Gnosis; , Kasyf". Hanya saja Alitheia adalah sebuah terminologi yang digunakan Heidegger. Lihat mengenai pembahasan ini dalam, Mistik Keseharian, h. 43

46 Derrida semacam menahbiskan diri bahwa pemikirannya merupakan lanjutan dari Heidegger selain Husserl dengan mengungkapkan; - Segala sesuatu yang diusahakan ini tidak mungkin tanpa lingkup keterbukaan yang dicaiptakan oleh pemikiran rujukan tanda dengan $\mathrm{T}$ besar, entah itu Roh, Spirit, ataupun Tuhan tapi yang kita temui selalu hanya jejaknya saja. Derrida mungkin tahu bahwa bahasa adalah rumah sang Ada, tapi sang Ada sendiri selalu tak dapat ditemui di dalam rumah yang itu-itu saja. Karena itu kita diajak menjelajahi setiap kemungkinan rumah sang ada dan berenang dalam lautan teks. Biarpun orang megatakannya nihilis, Derrida mungkin bersikukuh bahwa yang paling penting pada akhirnya bukan memergoki sang Ada dalam rumahnya, tapi perjalanan itu sendiri, dekonstruksi itu sendiri dan differance adalah sampannya.

Lalu bagaimana ia menjawab kerinduan manusia yang selalu berlayar di lautan tanpa dermaga? Bukankah dengan demikian ia terbuka dari ketidak adilan, kesemena-menaan dan makar? Dalam realitas yang kita terlempar (faktisitas) di sana, kita akan menemukan relativitas dan berurusan dengan keadilan Derrida berpegang-meminjam bahasa Goenawan Mohamad - dengan mengatakan bahwa -keadilan tetap sebagai sesuatu yang-masihbelum, "á-venir", Derrida menekankan pada suatu keadaan yang kini absen, yang berbeda dengan yang-masih-belum, yang senantiasa belum, nun di cakrawala waktu yang terbuka. ${ }^{47}$

Sekarang mari kita bayangkan bahwa pada tahun dimana Gatholoco diterbitkan adalah masa dimana kesalehan kamuflatif, kepatuhan kaku dan kerigidan tertentu. Kehadiran serat Gatholoco menginterupsi sekaligus mengintervensi kemonotonan ini. Dalam skema Derrida di atas, kita bisa menyejajarkan serat Gatholoco sebagai sebuah difference pada keadaan sosial. Orang disuruh berhenti sejenak dan meninjau ulang apa yang sesungguhnya terjadi, dan bagaimana seharusnya realitas dijalani.

Serat Gatholoco sebagai interupsi ini tak bisa berjalan sendiri, juga tak bisa menjadi biang kerok dari merosotnya moralitas. Di atas kita melihat secara historis gelombang protes dan pelarangan diedarkan atas serat ini.

Heidegger, (Positions, Paris, h. 18, dikutip dari K. Bertens, Filsafat Barat Abad XX, h. 493)

${ }^{47}$ Goenawan Mohamad, debu, duka, dsb, Jakarta: Tempo, h. 88 . 
Terlepas dari fakta bahwa serat ini merupakan olok-olok belaka, serat Gatholoco pada kenyataannya berhasil menginterupsi kemapanan beragama.

Aspek penting dari serat Gatholoco ini, bukan pada amoral dan anomalinya. Melainkan pada cara kerja teks itu sendiri. Kita lihat bagaimana reaksi orang beragamabaik yang terjadi di dalam teks - maupun yang benar terjadi di lapangan. Reaksi ini timbul akibat teks yang memuat satu unsur fenomenologis yang seringkali diabaikan, terutama setelah agama menyajikan kebenaran baku dan kepastian: pertanyaan.

Teks serat Gatholoco memuat sebuah unsur tunggal yang tak terbantahkan: yakni pertanyaan. Melalui teks ini kita bisa mempertanyakan bukan saja agama itu sendiri, tapi juga mempertanyakan Gatholoco. Maka kini kita bergerak pada tafsir dua arah. Ke dalam, ia bisa digunakan menyerang Gatholoco dan kandungan serat itu sendiri, sedangkan ke luar kita bisa melihat pertanyaan dengan lancar dilancarkan pada agama.

Karena itu sakralitas, teks, atatnan sosial yang baku dipertanyakan sedemikian rupa. Pertanyaannya adalah: oleh apa pertanyaan ini diajukan dalam serat serat Gatholoco. Jawabannya oleh pemahaman menyeluruh akan setiap kemungkinann paradoks dan ambivalen di dalam diri manusia. Karena setiap orang tahu bahwa tubuh (mencakup setiap organnya) memungkinkan pertentanganpertentangannya sendiri.

Tamsil bagi ini kita bisa lihat bagaimana struktur sosial kita bereaksi atas kata kontol dan intil dan terlepas dari aspek erotismenya sendiri. Erotik, pada dirinya sendiri adalah sifat imajinatif dari asosiasi organ tubuh manusia. jika ditelusuri jejaknya, erotisme tak pernah ada, karena bukan merupakan perwujudan dari anggota badan. Dan di sisi lain, organ badan mana pun pada dirinya sendiri tak pernah membawa visi dan asosiasi mengenai erotisme.

Karenanya dengan menggunakan Derrida kita bisa dengan santai menyebut bagian-bagian tubuh yang - terlarang dan biasa disebut sebagai -kemaluan dalam sistem sosial kita, tanpa terjebak ke kekeliruan tafsir. Berkenaan dengan teks serat Gatholoco, kita diharapkan untuk tidak terjebak. Dan berkenaan dengan realitas, kita juga bisa menerapkan hal serupa supaya tidak terjebak. Pada akhirnya kita akan menemukan sebuah kesejatian instrumental serat Gatholoco baik dalam konteks saat itu dan masa kini: yakni, sebagaimana Socrates, - hidup yang tak pernah dipertanyakan ulang, tak layak dihidupi. Oleh sebab itu, pemaparan erotisme dan fungsinya di dalam serat Gatholoco menyentuh aspek liturgi sakramental.

Perpaduan unsur kelelakian dan keperempuanan meniscayakan kehidupan. Lingkaran kosmologi mikrokosmis sedang terjadi dan, terlepas dari pretensi kritiknya yang sengit dan tajam, serat Gatholoco menemukan konteksnya sebagai teks.

\section{SIMPULAN}

Dalam simpulan ini, kiranya bisa dikerucutkan persoalan berkenaan dengan serat Gatholoco, baik itu pro dan kontra yang datang dari respons eksternal atas karya ini. Pendapat penulis, serat Gatholoco adalah kritik. Tapi karena sifatnya ayang afirmatif pada segala hal ihwal mengenai tubuh, maka kritiknya tak melulu berkenaan dengan ajaran Islam syariat. Lebih jauh, muatan kritik serat Gatholoco ini menyerang pada sikap ajaran asketisme dan kejuduhan.

Dari sudut pandang ini, menjadi kontras bahwa di satu sisi ada ajaran agama yang bergerak menjauh (menegasi aspek tubuh). Sedangkan di sisi lainnya lagi ada serat Gatholoco yang bergerak mendekat dan mengafirmasi tubuh. Dengan sumsi bahwa bahkan dalam hal yang dianggap laknat, wadag dan dumadi tak melulu najis, tak suci dan harus dijauhi. Karena pada hakikatnya, di tingkat hidup paling banal sekali pun, ada suatu kesejatian yang tak berpengaruh oleh segala sifat dan atribut yang dilekatkan padanya.

\section{DAFTAR PUSTAKA}

Annemarie Schiemmel, Dimensi Mistik Dalam Islam, (ed. Sapardi Djoko Damono, et. al) Pustaka Firdaus: 2000Astuti, Renggo. 1992-1993. Cangkriman. 
C. Jenks, Culture, Pustaka Pelajar: Yogya, 2013

Ensiklopedi Dunia Islam: Pemikiran dan Peradaban, Pt. Ikhtiar Baru Vanhouve: 2000.

F. Budihardiman, Heidegger dan mistik keseharian, jakarta: KPG, 2003.

Gayatri C Spivak, Membaca pemikiran Jacques Derrida; sebuah pengantar, Yogyakarta: Ar-Ruz, 2003.

Graaf dan Pigeaud. Kerajaan-Kerajaan Islam Di Jawa: Peralihan Dari Majapahit Ke Mataram. Ed. Soemarsaid Moertono. 1983. April. 1985

Goenawan Mohamad, Catatan Pinggir, (dengan judul Gatholoco), Pusat Data dan Analisa Tempo: 2005.

Jakarta: Tempo, 2011.

Jacques Derrida, Dekonstruksi Spiritual; merayakan ragam wajah spiritual, Yogyakarta: Jalasutra, 2002.

Joko Su'ud Sukahar, Tafsir Gatholotjo. 2007
K. Bertens, Filsafat barat Abad XX, Jilid II; Prancis, Jakarta: Gramedia, 1985.

Mulder, Niels. 1984. Kebatinan dan Hidup Sehari-hari Orang Jawa.

Muchtarom, Zaini. 1988. Santri dan Abangan di Jawa

Nyoman Kutha R, Antropologi Sastra; peran unsur-unsur kebudayaan dalam proses kreatif, Pustaka Pelajar: Yogya, 2011

Peursen, Van. Strategi Kebudayaan, 1988.

Ronggowarsito, Zaman Edan, Bentang: Yogya, 2002

\section{Majalah\& Jurnal:}

Majalah Basis (Edisi Khusus Derrida), No. 1112, Tahun 56-November-Desember, 2007. (Edisi Khusus Derrida),No. 1112, Tahun 54-November-Desember, 2005. Jurnal Kebudayaan Kalam, Edisi, 5, Th. 1995 